\title{
The Impact of Leadership Communication and Empowerment on Job Motivation Amongst Public Sector Employees in Malaysia
}

\author{
WAN ABD AZIZ WAN MOHD AMIN \\ MOHD SHALADIN MUDA \\ NIK WAN OMAR \\ Collage Sciences and Technology \\ Universiti Malaysia Terengganu
}

This paper describes a research project that investigated the influence of leadership communication and staff empowerment on job motivation among civil servants. The aim was to fill a gap in the management literature, especially in the Malaysian perspective under the dynamic context of the recent civil servant empowerment practices between state and federal agency departments. Three dimensions on leadership - communication had been examined, namely, initiating structure, consideration, and communication orientation, and their link with empowerment and job motivation. A face-to-face survey was performed on 198 respondents from five state agency departments and five federal agency departments using a stratified random sampling technique. As well as the importance of literature contribution, some of the conclusions from this study can give an important insight for the Malaysian practitioners in public sector management. Part of the conclusion suggests that the consideration dimension is proven to be able to encourage empowerment practice and consequently would increase staff motivation. Another finding is

- that leadership communication based on the three dimensions above is better practised in the federal agencies than the state agencies. The study also proved that leadership communication, empowerment, and forecast factors would contribute toward the increase of motivation among workers.

\begin{abstract}
ABSTRAK
Artikel ini menghuraikan projek penyelidikan yang mengkaji pengaruh komunikasi kepimpinan dan 'empowermen' kakitangan ke atas motivasi kerja dalam kalangan pekerja di sektor awam. Tujuannya untuk menambahkan sorotan karya dalam pengurusan lebih-lebih lagi di Malaysia dalam konteks perkhidmatan awam dan 'empowermen' antara Kerajaan Negeri dan Persekutuan. Tiga konstruk komunikasi kepimpinan telah dibentuk iaitu merintis struktur, pertimbangan dan orientasi komunikasi, yang akan mengkaji hubungan dengan 'empowermen' dan motivasi kerja. Temuduga bersemuka telah dibuat ke atas 198 pekerja daripada lima agensi negeri dan lima daripada agensi persekutuan menggunakan persampelan rawak berlapis. Selain daripada kepentingannya kepada literatur, kajian juga menyumbang kepada amalan pengurusan dalam sektor awam di Malaysia. Rumusan kajian mendapati dimensi pertimbangan terbukti dapat menggalakkan 'empowermen' dan seterusnya meningkatkan motivasi di kalangan kakitangan. Dapatan lain mendapati amalan komunikasi kepimpinan berasaskan kepada tiga dimensi tersebut lebih baik di agensi awam persekutuan berbanding dengan agensi awam negeri. Dapatan kajian memberikan gambaran bahawa amalan komunikasi kepimpinan yang melibatkan ketiga-tiga dimensi iaitu merintis struktur, pertimbangan dan orientasi komunikasi ketua
\end{abstract}


adalah lebih baik dalam agensi persekutuan berbanding dengan agensi negeri. Dapatan kajian juga dapat membuktikan bahawa komunikasi kepimpinan, empowermen dan faktor peramal menyumbang kepada peningkatan motivasi dalam kalangan pekerja.

\section{INTRODUCTION}

This paper describes a research project that investigates the influence of leadership communication and staff empowerment on job motivation among the civil servants. The aim was to fill a gap in the management literature, especially in the Malaysian perspective under the dynamic context of the recent civil servant empowerment practices between state and federal agency departments. Three dimensions on the leadership communication have been examined,

namely, initiating structure, consideration, and eommunication orientation, and their link with empowerment and job motivation.

The objectives of this study were;

to determine the positive relationship between leadership communication with empowerment;

to determine the positive relationship between leadership communication with job motivation;

to determine the positive relationship between empowerment has any relation with job motivation; and

to measure the contribution of leadership communication, empowerment, and other predictor factors influences job motivation.

Many studies have been done on the eadership styles and job motivation (Hopkins 995; Smith 1992; Bucke, Stagl, Klein, Goodwin, Salas, \& Halpin, 2006). Nevertheless little research is performed on the aspect of relationship between leadership communication, empowerment, and job motivation. For example, a research by Abdul Halim Busari and Eng (2003) from the Agriculture Department, Malaysia, investigated the relationship between different styles of leadership on employee motivation. They found that there is a positive correlation between leadership styles and employee motivation. Authors such as Eskildsen et al. (2003) claimed that one of the determinants of job motivation is leadership style. Other factors are condition of work, corporate image, and cooperation. According to Hersey and Blanchard (1974), and Locke $e t$ al. (1991), leadership style is a way used by leaders to influence people, while motivation refers to the willingness to exert high levels of effort to reach organisational goals, conditioned by the effort's ability to satisfy some individual needs (Robbins, 2002). Abd Halim Busari and Eng (2003) claimed that in order to increase employee motivation and obtain better worker performance, leaders should show a good role to their followers by showing persistence and determination in the pursuit of organisational objectives, exhibiting creative talents and strategies when facing challenges at work, having high standards of ethical and moral conduct, sacrificing self-gain for the benefits of others, and encouraging workers to use their imagination in problem solving.

Recently there has been growing concern about the role of leaders especially on how they communicate with their employees. Goldhaber (1992) argued that leadership communication practice, which is based on initiating structure, consideration, and communication orientation, need to be emphasised in order to boost the effectiveness of interpersonal communication among the respective organisation members. Initiating structure refers to a leader who arranges and plans relations with higher authority and lower employees, and plays an active role in doing the job, how it is done, and when it will be finished. Consideration is a label for leader behaviour which is close to social relationships and group cohesion. In general, the relationship between the leader and subordinate is reflecting a two-way communication, mutual respect, trust, and emphasis on satisfying employee needs (Bucke, Stagl, Klein, Goodwin, Salas, \& Halpin, 2006). These leaders are very considerate towards their subordinates. Baktiar (1995) claimed that there are six pre-conditions which are core in creating psychological closeness 
for a manager who leads an organisation in an effort to motivate his employees. 1) empathy - understanding subordinates; 2) unconditional acceptance - an individual has to be accepted without taking account of their family background, economic status, physical traits, behaviour and life principles; 3 ) sincerity - free from any hypocrisy, no arranged agendas, no malicious intent, and do not manipulate staff for own advantages; 4) openness - accepting other opinion, differences in view does not mean an objection, and variety is regarded as enrichment and progress elements; 5) concrete - specific and objective in facing the issues; and 6) helping skill - referring to high basic communication skills.

Regarding communication orientation, Jaafar (2000) claimed that management tasks will not be accomplished without the leader's ability to create and maintain a job environment and atmosphere that enables leaders and workers to cooperate in groups towards the attainment of similar goals. Similar opinion is also emphasised by Scott (1999) who claimed that team spirit or esprit de corps among dedicated workers even in small groups would be able to solve many problems in an organisation. This idea was supported by Carol, Larson, and Steven (2000) who claimed that teamwork and cooperative practice between units are vital. High teamwork spirit would enable the employer to encourage the creation of problem-solving teams that would benefit many parties (Carol et al., 2000).

Empowerment is defined as a process which leads to enhanced perceptions of self-efficacy among followers by identifying conditions that foster a sense of powerlessness and removing them through both formal organisational practices and informal techniques (Conger \& Kanungo, 1998; Spretzer, 1995; 1996). There are two aspects of empowerment that need to be understood. The first is personal empowerment, which refers to the individual responsible doing for them in order to feel empowered in their lives regardless of circumstances. The second is working with others to nurture their sense of self-esteem, autonomy, and growth (Pastor, 1996). In this study, empowerment refers to the given responsibility and power to the employees in efforts to solve any work related problem within their job scope.

Job motivation refers to those behaviours which promote team members exerting continued effort in pursuing higher job performance in efforts to achieve organisational goals. According to Ahmad Atory (1996) and Fleishman, Mumford, Zaccaro, Levin, Korotkin, and Hein, (1991), motivation includes reward and recognition of performance as well as behaviours which ensure that the needs and values of members are met through the provision of support for individuals for their efforts. Kappelman and Richards (1996) and Smith, (1992) claimed that empowerment has a positive correlation with worker motivation and job satisfaction. Kappelman and Richards (1996) also argued that giving workers the opportunity to schedule their own training would result in large increases in employee motivation in response to the change, and in their overall satisfaction levels.

The problems related to motivation among civil servants have become more apprehensive. A lot of complaints have been heard from the general public regarding their dissatisfaction towards the level of government services. This situation was emphasised by the YAB Prime Minister's statement at Majlis Perdana Perkhidmatan Awam Keenam (MAPPA VI, 2005) who stressed that there were civil servants who were not well responsive, still unchanged, and have not showed high quality work performance (Utusan Malaysia, 21 January 2005). Employees with low motivation can give negative impact towards the organisation since it is associated with the level of employee job satisfaction. Job dissatisfaction among employees can cause problems such as absenteeism, lateness, carelessness, long periods leave of and many more which in turn can affect the quality of organisation's performance (Bruce \& Blackburn, 1992; Gruenberg, 1979; Lawler, 1973; Vroom, 1992). Based on the discussion of literature and problem statement of the study, the following conclusion is found that the factors of leadership communication and empowerment therefore need to be emphasised by government in order to ensure that motivation among civil servants can remain at a good level. 
The development of a path model was based on a conceptual framework and the links between certain demographic and motivation were elaborated in the conceptual framework. The path values were derived from regression analysis, which are the beta coefficients.

\section{RESEARCH METHODOLOGY}

The population of this study was 868 employees of 10 public agencies, whereby five were from federal agencies with 351 employees, and another - five from state agencies with 517 employees. According to Sekaran (2003) based on the given population, a 265 sample size is the minimum requirement needed in this study.

A proportionate stratified random sampling was used where $30 \%$ respondents from each - organisation were selected. This means that 106 respondents from each federal agency and 154 respondents from each state agency were collected. Among them, only $74.7 \%$ or 198 respondents were qualified for data analysis. The respondents have to answer the questions by marking the provided scales. The questionnaire contained four sections, - which are as follows:

Section A: Leadership Communication

ii) Section B: Empowerment

iii) Section C: Job Motivation

iv) Section D: Self information

\section{Section A: Leadership Communication}

This section consisted of 50 questions; 20 questions for leadership communication, 20 questions for consideration leadership, and 10 questions for communication orientation. The questions were designed based on the research by Ohio State University study on the leadership behaviour. Respondents were asked questions based on scale of 1 to 5 , with a sequence of "never", "seldom", "sometimes", "frequently" and "always" respectively.

\section{Section B: Empowerment}

This section contained 15 questions used to measure empowerment practice. It has been modified by the researchers based on the original work of Short and Rhinehart (1992) to suit the usage in public agencies. Empowerment is measured by using three dimensions that are making decision (4 questions), professional development (5 questions), and status (6 questions). The scale used the measure of 1 to 5 to represent "most disagreed", "disagreed", "neutral", "agreed" and "most agreed".

\section{Section C: Job Motivation}

In order to measure job motivation, a measuring tool based on work of Sutarto (1997) was used. This measuring tool measures an individual motivation achievement in their profession. It contains nine questions altogether, in order to evaluate the overall achievement motivation. The level of achievement motivation was assessed by marking on the determined scale of 1 to 5 , which was "most disagreed", "disagreed", "not sure", "agreed" and "most agreed".

\section{Section D: Self Information}

This section possessed nine questions that were related to respondents' demographic background. Items that are included in this section were gender, age, service duration with present department, marriage status, income, highest academic qualification, service group, and department status (whether state or federal agencies).

\section{PILOT STUDY}

A pilot study was performed on 48 staff members of the Terengganu Foundation department. The engaged respondents were separate from the respondents in the actual study. Findings from the study showed that the amount of time taken to answer all the questions was between 20 to 30 minutes. Based on Table 1, the alpha coefficient values for every variable were quite high and exceeded the value of 0.6 , which according to Sekaran (2003), is considered suitable and acceptable.

There are two dependent variables identified in the study which were job motivation and empowerment. The 'stem and leaf' diagram for both the state and the federal agencies found that 
Table 1

Alpha Reliability for Pilot Study

\begin{tabular}{lcccccc}
\hline Dimension /variables & $\begin{array}{c}\text { Alpha } \\
\text { (pilot test } \\
\mathrm{N}=48)\end{array}$ & $\begin{array}{c}\text { Alpha } \\
(\mathrm{N}=198)\end{array}$ & $\begin{array}{c}\text { Mean } \\
\text { Score } \\
\text { (public } \\
\text { agencies) }\end{array}$ & SD & $\begin{array}{c}\text { Mean score } \\
\text { (state } \\
\text { agencies) }\end{array}$ & SD \\
\hline Leadership Communication & & & 204.07 & 31.89 & 193.29 & 33.11 \\
Orientation Communication & 0.86 & .75 & 54.33 & 9.43 & 53.32 & 9.82 \\
Initiating Structure & 0.86 & .81 & 73.50 & 10.60 & 69.03 & 11.96 \\
Consideration & 0.95 & .93 & 76.23 & 15.02 & 70.94 & 14.36 \\
Empowerment & & & 56.77 & 10.46 & 53.91 & 5.72 \\
Decision Making & 0.70 & .69 & 14.80 & 2.94 & 14.25 & 1.92 \\
Professional & 0.78 & .79 & 19.33 & 4.18 & 17.92 & 2.53 \\
Status & 0.80 & .81 & 22.63 & 3.95 & 21.75 & 2.78 \\
Sob Motivation & 0.73 & .72 & 18.83 & 4.84 & 20.22 & 4.32 \\
\hline
\end{tabular}

(1)

there were several cases of interesting values for both agency data. In ensuring that these values do not affect the analysis, especially those that were related with regression, a standardised residual value method and Cook's distance were done. Analysis on standardised residuals on job
motivation is necessary to monitor the presence of extraordinary values of respondents for both state and federal agencies. Residue is the difference between observed values in the dependent variable with expected values by the regression Time (Norusis, 1995). Therefore two series of regression analysis were done on the state and federal agencies job motivation variables in order to get the list of standardised residuals.

Standardised residuals can be obtained dividing the residuals with the standardised deviation estimation for the residuals. From the list, it was found that there were two cases where the standardised residuals was more than 2, which is $1.9 \%$ of the data from the state agencies. Thus $98.1 \%$ from the job motivation standardised residual data for state agencies are within normal distribution. Meanwhile, for federal agencies, there was only one case that had standardised residual value of more than 2 . This only represented $1.1 \%$ of the overall data, meaning that the remaining $98.9 \%$ of data were within the normal distribution.
A review on similar data by examining Cook's distance values for both state and federal agencies also showed that data for job motivation variables of those agencies were normal. This was proven with non-existence of federal and state agency Cook's distance values of more than 1. If the Cook's distance value is larger than 1 , it would affect the normality assumption in data distribution (Norusis, 1995).

Although both data on job motivation for state and the federal agencies exhibited several extraordinary values through the Stem and Leaf Plot diagram, yet confirmation through standardised residuals and Cook's distance values, showed that the respective data did not affected the normality assumption. When a histogram on job motivation standardised residuals for both agencies was plotted, the graph showed a slight deviation from the normal curve and this situation is caused by variation in sampling (Norusis, 1995). This matter however, is still able to explain the normality in data for the dependent variable of both agencies.

The following normality test was done by plotting standardised residuals in the form of normal proportion-proportion or normal p-p plot. Normal $p-p$ plot actually describes a scatter plot for cumulative score distribution of a variable with normal distribution. If a variable is within normal 
distribution, the dots in the diagram would form a straight line. It was found that the dots were grouped along a straight line. This circumstance signified that normality assumption was once more fulfilled.

In determining the relationship between variables is linear, it can be done by plotting standardised residuals of a variable with the predicted values (Norusis, 1995). If the relationship is linear, the points in the diagram will scatter randomly and not form a curve. This would prove that the existence of linear relationship between variables is achieved. Next is the determination of multicolinearity. Multicolinearity is a state that - exists where every independent variable that is included in the multiple regression analysis will have high level of correlation with each other. This situation will reduce the values of regression coefficient trustworthiness and it can affect the accuracy of the analysis, as in the efforts to provide the answer on the submitted hypothesis. The presence of high multicolinearity is showed through looking at tolerance and Variance of Inflation Factor (VIF) values. The occurrence of low values of tolerance, which is less than 0.1 , and values of VIF, which is more than 10, indicate high multicolinearity.

\section{RESULTS}

From the 260 distributed sets of questionnaire, 198 sets were returned and used for data analysis. This gave the returning rate of $76 \%$. From the numbers, 108 sets represented state agencies and another 90 sets were from federal agencies. Description on the respondent demographic profile are summarised in Table 2. Based on Table 2, among the respondents were $60.1 \%$ male workers (119 workers) and 39.9\% female workers (79 workers). The majority of respondents were middle aged, where $46.5 \%$ (92) were within 36 to $45,8.1 \%$ (16) were aged less than 25 years old, $16.2 \%$ (32) were aged between 26 to 35 , and $27.3 \%$ (54) were aged between 46 to 55 . These percentages are able to explain that majority of the respondents possess a long service duration and were very experienced workers.

Most respondents have a medium level of education, because almost 46.6\% (91) have MCE/
SPM qualification, meanwhile the remaining respondent education level were LCE/SRP/PMR 7.1\% (14), STP/STPM 19.7\% (39), Diploma $8.1 \%$ (16), Bachelor Degree of (16.7\%) and Master Degree (2.5\%), with 3 and 5 respondents for each respectively. In terms of service group, they were from the support group II (68.2\%) which were 135 people, while the rest $10.1 \%$ were from the support group I (20 people), and $21.7 \%$ from Professional and Management group (43 people).

The majority of the respondents were married with percentage of $78.8 \%$ (156 people) and $19.2 \%$ (38 person) were single, and the rest 4 respondents $(2.0 \%)$ were widowed. Table 2 also showed that $12.6 \%$ (25) from the respondents had worked less than 3 years, while the remaining 46 people $(23.2 \%)$ had worked at their respective departments between 4 to 7 years. However, the highest number of the respondents worked for more than 16 years (37.9\%). This situation showed that the respondents possed a wide job experience and deeper knowledge that are related to their profession. This study also illustrated that more than half of respondents $(69.2 \%)$ or 137 people, work in direct control of their bosses in Professional and Management group, and followed by $21.7 \%$ (43) bosses in support group II, and the rest were 18 people under supervision of bosses from support group 1 .

\section{Issue 1: Does Leadership Communication have a Relationship with Empowerment?} The findings demonstrated the existence of significant positive relationship between leadership communications with empowerment for both state and federal agencies. The positive relationship meant that an increase in leadership communication will at the same time steer empowerment practice towards better direction. It too can be proof of organisational effectiveness, especially those that are link with empowerment which also depend on status of leadership communication among managers who lead the organisation.

The positive relationship was clearly displayed in the three leadership styles. Leadership communication in the form of initiating structure was linked with empowerment with value of $r=$ $0.42, \mathrm{p}<0.01$ for state agencies, and $\mathrm{r}=0.54, \mathrm{p}<0.01$ 
Table 2

Demopraphic Profile of Respondent

\begin{tabular}{lccc}
\hline Profile & Frequency & Percentage & Cumulative \\
& $(\mathrm{N}=198)$ & $(\%)$ & Percentage \\
\hline
\end{tabular}

\section{Gender}

Male

Female

Age (years)

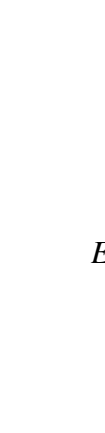

21-25

26-30

31-35

$36-40$

41-45

$>45$

Education

S.R.P/L.C.E/P.M.R

S.P.M/M.C.E

S.T.P/S.T.P.M

Diploma

- Bachelor Degree

Master Degree

Services Group

Support staff II

Support Staff I

Mgt \& Professionals

Status

- Single

Married

Widow

Years of Services

$<4$

4-7

8-12

12-15

$>15$

Department Status

State

Federal

Services Group near the leader

Support staff II

Support Staff I

Mgt \& Professionals

\section{9}

79

16

32

28

38

54

30

14

91

39

16

33

5

135

20

43

38

156

4

25

46

39

13

75

108

90

43

18

137
60.1

39.9

8.1

16.2

14.1

19.2

27.3

15.2

7.1

46.6

19.7

8.1

16.7

2.5

68.2

10.1

21.7

19.2

78.8

2.0

12.6

23.2

19.7

6.6

37.9

54.5

45.5

21.7

9.1

69.2
60.1

100.0

8.1

24.2

38.4

57.6

84.4

100.0

7.1

53.0

72.7

80.8

97.5

100.0

68.2

78.3

100.0

19.2

98.0

100.0

12.6

35.9

55.6

62.1

100.0

54.5

100.0

21.7

30.8

100.0 for federal agencies. However, that relationship was found stronger for federal agencies, yet both were still at a high level of significance. In this matter, leaders at state agencies need to improve their leadership communication practices especially those applying a structure initiating style on the staff. For the relationship between consideration leadership and empowerment, findings illustrated that there is a wide gap of relationship strength if observed for both agencies. This was shown with value of $\mathrm{r}=0.38, \mathrm{p}<0.01$ for state agencies, and $\mathrm{r}$ $=0.62, \mathrm{p}<0.01$ for federal agencies. The difference 
of almost half of the value requires serious effort among state organisation leaders in improving leadership style at that particular agency.

Related to the relationship between communication orientation, results also showed a similar trend where the relationship was still strong at federal agencies $(\mathrm{r}=0.53, \mathrm{p}<0.01)$, compared to state agencies $(r=0.44, p<0.01)$. The similar explanation and steps from the aspect of leadership communication need to be developed in order to boost the level of empowerment at respective agencies.

Research on relationship of leadership communication with empowerment also can be - seen from the aspect of respondents' demographic. Relationship between structures initiating leadership variable, consideration leadership, and communication orientation with empowerment are observed based on gender, age, service group, service duration, and leader service group.

- The results showed that the influence of external variables on relationships between initiating structure leadership variable, consideration leadership, and communication orientation with empowerment, were varied depending on the type of agency. It illustrated that for state agencies, the staff service group external variable played a large role in influencing relationships between independent and dependent variables. The findings showed that service groups have been found to influence those three relationships between initiating structure leadership with empowerment, consideration leadership with empowerment, and communication orientation. This showed that employee service groups for state agencies are very influential in determining the relationship between the role that is played by leaders through their leadership communication, with the empowerment position that has been given to employees. Other external variables demonstrated different roles for all three leadership communication variables in influencing its relationship with empowerment.

For the federal agencies, findings showed that employees' service duration and leaders' service groups who supervise the involved employees' assignment gave a major influence on the relationship between structure initiating leadership external variable, consideration leadership, and communication orientation with the empowerment dependent variable. This is because both external variables exhibited influence on the three studied relationships. This result is rather different from the state agencies in two unique aspects, which are the types of external variable and their numbers that showed the particular influence. This indicated that different variables played different roles in different agencies. In the context of the federal agencies themselves, staff is service duration and leaders' service group contribute significant influence in determining the role of leadership communication on empowerment distribution level.

Table 3

Correlations between Variables based on Federal Agencies

\begin{tabular}{|c|c|c|c|c|c|c|}
\hline & & motivasi & oriekomu & merintis & pertimba & allempow \\
\hline \multirow[t]{3}{*}{ motivation } & Pearson & 1 & $-.370(* *)$ & $-.527(* *)$ & $-.618(* *)$ & $-.675(* *)$ \\
\hline & Sig. (1-tailed) & & .000 & .000 & .000 & .000 \\
\hline & $\mathrm{N}$ & 90 & 90 & 90 & 90 & 90 \\
\hline \multirow[t]{3}{*}{$\begin{array}{l}\text { Orientation } \\
\text { communication }\end{array}$} & $\begin{array}{l}\text { Pearson } \\
\text { Correlation }\end{array}$ & $-.370(* *)$ & 1 & $.698(* *)$ & $.657(* *)$ & $.534(* *)$ \\
\hline & Sig. (1-tailed) & .000 & ${ }^{\circ}$ & .000 & .000 & .000 \\
\hline & $\mathrm{N}$ & 90 & 90 & 90 & 90 & 90 \\
\hline
\end{tabular}


(continued)

\begin{tabular}{|c|c|c|c|c|c|c|}
\hline \multirow[t]{3}{*}{ Initiating structure } & $\begin{array}{l}\text { Pearson } \\
\text { Correlation }\end{array}$ & $-.527(* *)$ & $.698(* *)$ & 1 & $.829(* *)$ & $.540(* *)$ \\
\hline & Sig. (1-tailed) & .000 & .000 & . & .000 & .000 \\
\hline & $\mathrm{N}$ & 90 & 90 & 90 & 90 & 90 \\
\hline \multirow[t]{3}{*}{ Consideration } & $\begin{array}{l}\text { Pearson } \\
\text { Correlation }\end{array}$ & $-.618(* *)$ & $.657(* *)$ & $.829(* *)$ & 1 & $.619(* *)$ \\
\hline & Sig. (1-tailed) & .000 & .000 & .000 & & .000 \\
\hline & $\mathrm{N}$ & 90 & 90 & 90 & 90 & 90 \\
\hline Empowerment & $\begin{array}{l}\text { Pearson } \\
\text { Correlation }\end{array}$ & $-.675(* *)$ & $.534(* *)$ & $.540(* *)$ & $.619(* *)$ & 1 \\
\hline & Sig. (1-tailed) & .000 & .000 & .000 & .000 & . \\
\hline & $\mathrm{N}$ & 90 & 90 & 90 & 90 & 90 \\
\hline
\end{tabular}

Table 4

Correlations between Variables based on State Agencies

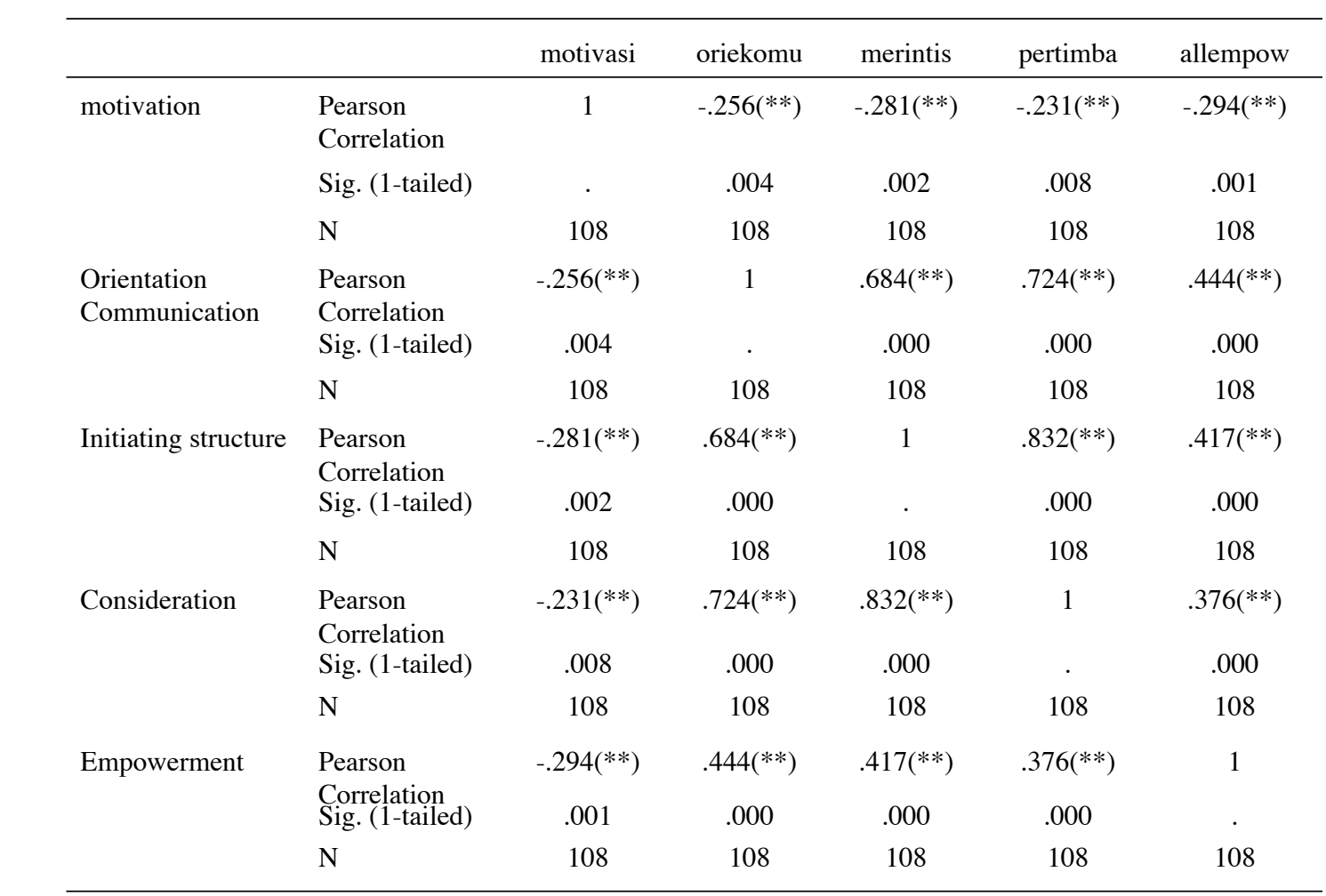

** Correlation is significant at the 0.01 level (1-tailed). 


\section{Issue 2: Does Leadership Communication} have a Relationship with Job Motivation?

The findings showed that there is a significant positive relationship between communication orientations with motivation for both agencies. However, the relationship is firmer with higher significant levels in federal agencies. This can be seen through $\mathrm{r}$ value for state agencies, where $r=0.28, p<0.05$ for relationship between initiating structure with motivation, $r=0.23$, $>p<0.05$ for relationship between consideration leadership and motivation, and $r=0.26, p<0.05$ for relationship between communication orientation with motivation, compared to $\mathrm{r}=$

- 0.53, $\mathrm{p}<0.01 ; \mathrm{r}=0.62, \mathrm{p}<0.01 ;$ and $\mathrm{r}=0.27$, $\mathrm{p}<0.01$ each for federal agencies, respectively. Looking to $r$ values for state and federal agencies especially on the relationship between initiating structure and consideration leadership with motivation, the difference in $r$ values between

- both agencies is large. This signifies that the difference in relationship firmness between variables is good. The differences in values between the two variables are able to confirm the strength of a relationship. For the state agencies, more efforts need to be given in order to make the leadership communication become more positive as to further strengthen the relationship between components within communication and motivation, which at the end would boost the motivation among involved employees.

In discussing the role of demographic variables, findings for the state agencies showed that only gender influenced the relationship for the three dimensions in leadership communication with job motivation. For the state agencies demographic variables displayed prominent role in influencing the relationship where three of five variables such as age, service duration, and leaders' service group showed influences on the relationship for all three dependent and independent variables.

The above results demonstrated that the relationship of leadership communication among the leaders with motivation among the staff especially for federal agencies, is also influenced by factors that are related to workers' demography.

\section{Issue 3: Does Empowerment have a Relationship with Job Motivation?}

Three components of empowerment which are decision making, professional, and status development have been tested of their relationship with motivation. Findings displayed obvious differences in relationship between empowerment and job motivation for both agencies. For the state agencies, results showed that decision making is not significant with motivation, meanwhile for federal agencies, $r$ value for referred relationship was $r=0.50 . p<0.01$, which indicates a rather firm relationship. This means that state agency empowerment practice, especially which involves freedom for a worker in making decision, is less given by the respective leaders. In this situation empowerment especially on decision making does not contribute to motivation among employees.

\section{Issue 4: Do leadership communication, empowerment, and other predictor factors have any influence on job motivation?} Comparatively. based on the two diagrams below (Figure 2 and 3), it is clear that factors that influence motivation are different for both agencies. For the state agencies, two significant factors that contribute towards that direction are service group and empowerment. On the other hand, for the service group, direct contribution to the motivation showed a negative value which indicates that workers in higher service group (Management and Professional) have lower motivation level compared to staff in lower service groups (Support I and II). Nevertheless, with the empowerment distribution to the employees especially for Management and Professional group, it has indirectly increased the level of motivation among them. Findings also displayed that contribution of predictors to the empowerment and motivation is quite low (23.8\% and $14.4 \%$ each) compared to the federal agencies.

Findings from the path analysis model for the federal agencies showed that there were five factors that contribute to the achievement of motivation among them. The factors are gender, communication orientation, empowerment 
Table 5

Model Summary of State Agencies Job Motivation

\begin{tabular}{|c|c|c|c|c|c|c|c|c|}
\hline \multirow[t]{2}{*}{$\mathrm{R}$} & \multirow[t]{2}{*}{ R Square } & \multirow[t]{2}{*}{$\begin{array}{l}\text { Adjusted R } \\
\text { Square }\end{array}$} & \multirow[t]{2}{*}{$\begin{array}{l}\text { Std. Error of } \\
\text { the Estimate }\end{array}$} & \multicolumn{5}{|c|}{ Change Statistics } \\
\hline & & & & $\begin{array}{l}\text { R Square } \\
\text { Change }\end{array}$ & $\begin{array}{c}\mathrm{F} \\
\text { Change }\end{array}$ & df1 & df 2 & $\begin{array}{l}\text { Sig. F } \\
\text { Change }\end{array}$ \\
\hline $.456(a)$ & .208 & .144 & 3.99834 & .208 & 3.253 & 8 & 99 & .002 \\
\hline
\end{tabular}

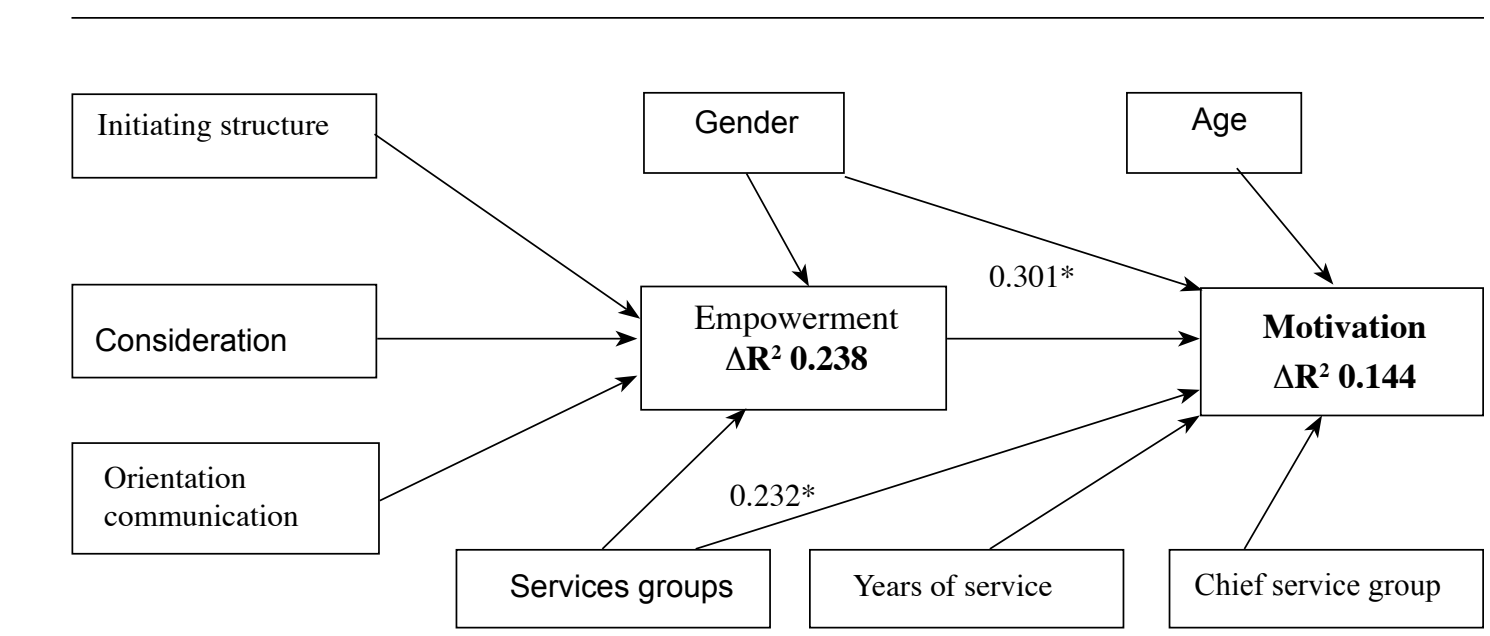

Figure 2

Path Analysis Model of state agencies job motivation

and service group of leaders who supervise the workers' task. Another factor that gives contribution through empowerment is the one that related to consideration leadership style. Contribution of demographic factors and leadership communication on empowerment is high, which is - $44.9 \%$. This contribution increased to $49.1 \%$ when the empowerment factor is included in the model. This showed that empowerment plays a role in enhancing motivation by contributing an amount of $4.2 \%$. Another finding from Figure 3 showed that leader service group displayed negative influence on motivation. This can be explained, as the higher the leaders' service group or the wider of the gap of post hierarchy between workers and leaders who supervise them, the lower the level of achievement motivation among the workers.

\section{Table 6}

Model Summary of Federal Agencies Job Motivation

\begin{tabular}{|c|c|c|c|c|c|c|c|c|}
\hline $\mathrm{R}$ & $\begin{array}{c}\mathrm{R} \\
\text { Square }\end{array}$ & $\begin{array}{l}\text { Adjusted } \\
\text { R Square }\end{array}$ & $\begin{array}{l}\text { Std. Error of } \\
\text { the Estimate }\end{array}$ & \multicolumn{5}{|c|}{ Change Statistics } \\
\hline & & & & $\begin{array}{c}\text { R Square } \\
\text { Change }\end{array}$ & F Change & df1 & df2 & Sig. F Change \\
\hline $.780(a)$ & .608 & .569 & 3.17901 & .608 & 15.707 & 8 & 81 & .000 \\
\hline
\end{tabular}


yet its presence is significant to ensure the smooth flow of work. A positive working environment that is produced from the effectiveness of leadership communication practices needs to be focused on and spread into other organisations because it is the main contributor to increase the quality of an organisation.

This study has implications for the management. Based on the results of the study, the management should concentrate on the dimensions of leadership communication which are significantly correlated with job motivation for the employees. Since the significant correlation is between consideration and empowerment, it is recommended that policies should be put in place, Where it will enhance the motivation amongst the employees.

\section{(1)}

\section{LIMITATIONS OF THE STUDY}

There are some shortcomings with regard to the research design and methodology of this investigation. Firstly, the study focused on the relationship between leadership communication yith job motivation, via empowerment among public sector in federal agencies and state - agencies. Secondly, the study was conducted only in Terengganu and thus the findings may not be applicable to all public sectors in Malaysia.

\section{REFERENCES}

- Abdul Halim, B. \& Eng, S. C. (2003). Relationship between leadership styles and employees' motivation. Proceedings National Human Resource Development Conference. UMS Sarawak. Pg.167-175.

Ahmad Atory, H. (1996). Pengurusan organisasi. Utusan Publication and Distributors Sdn. Bhd.

Baktiar, M. (1995). Motivasi dalam pengurusan perspectif kaunseling. Journal Pengurusan Pendilean.
Bass, B. M. (1985). Leadership and performance beyond expectations. New York: Free Press.

Bucke, C. S., Stagl, K. C., Klein C., Goodwin, G. F., Salas E., \& Halpin S. M. (2006). What type of leadership behaviours are functional in teams? A Meta-analysia. The Leadership Quarterly, 17, 288-307.

Burke, W. W. (1986). Leadership as empowering others. In S. Srivasta (Ed.). Executive power (pp.51-77). San Francisco, CA: Jossey-Bass.

Bruce, W. M., \& Blackburn. J. W. (1992). Balancing job satisfaction \& performance: A guide for human resource professionals. Westport. Connecticut:Quorum Books.

Carol, A. T., Larson, R., \& Steven. H. F. (2000). Hanging on or fading out? Job statisfaction and the long-term worker. Public Personnel Management, 29 (3) 343-351.

Choi, J. (2006). A motivational theory of charismatic leadership: Envisioning. empathy .and empowerment. Journal of Leadership and Organisational Studies, $13(1)$

Conger, J. A., \& Kanungo, R. N. (1998a). The empowerment process: Late grading theory and practice. Academy of Management Review, 13, 471- 482.

Conger, J. A., \& Kanungo, R. N. (1998). Charismatic leadership in organisations. Thousand Oaks. CA: Sage.

Erika, L. (2000). Tooling for leadership. Professional Manager. Nov, 10-12.

Fleishman, E. A., Mumford, M. D., Zaccaro, S. J., Levin, K. Y., Korotkin, A. L., \& Hein, M. B. (1991). Taxonomic efforts in the description of leader behaviour: A synthesis and functional interpretation. Leadership Quarterly. 4, 245-287. 
Gruenberg, M. M. (199). Understanding job satisfaction.London:McMillan Press Ltd.

Hopkins, H. (1995). A challenge to managers: Five ways to improve morale. Executive Development, 8 (7), 26-28.

Jaafar, M. (2000). Kelakuan organisasi. (4th ed.). Kuala Lumpur: Leeds Publications.

Kappelman, A. L., \& Richards, C. T., (1996). Training empowerment and creating a culture for change. Empowerment in Organisation, 4 (3), 26-29.

Lawler, E. E. (1973). Motivation in work organisations. Belmont. CA: Books/ Cole.

Vroom, V. H. (1992). Work and motivation. Malabar. FL: Robert E. Kreger Publishing Co.

Norusis, M. J. (1995). SPSS 6.1 Guide to Data Analysis. New Jersey: Prentice Hall.

Pastor, J. (1996). Empowerment in Organisations, 4 (2), 5-7.

Robbins, S. P. (2002). Organisational behaviour. Prentice Hall.

Scott. C. (1999). Using five motivational germs for a brilliant performance. Long Island Business News. Vol. 46 Issue 5.

Sekaran, U. (2003). Research methods for business. A skill-building approach. New York: John Wiley \& Sons Inc.
Shawn, B. C et al. (2006). What type of leadership behaviours are functional in teams? A Meta-analysis. The Leadership Quarterly, 17. 288-307.

Short, P. M., \& Rhinehart, J. S. (1992). School participant empowerment scale: Assessment of level of empowerment within the school environment. Educational and Psychological Measurement, 52 (4), 951960.

Smith, B. (1992). Empowerment - the challenge is now. Empowerment in organisations. 5 (3), 120-122.

Speitzer, G. M. (1995). Psychological empowerment in the workplace: Dimensions. measurement and validation. Academy of Management Journal, 38, 1442-1465.

Spreitzer, G. M. (1996). Social structural characteristics of psychological empowerment. Academy of Management Journal, 39, 483-504.

Sutarto, W. (1997). Hubungan Di Antara Motivasi Kerja Dan Personality Dengan Prestasi Kerja Sesebuah Organisasi. Unpublished Master Thesis. Jabatan Psikologi. Universiti Kebangsaan Malaysia.

Stogdill, R. M. (1924). Handbook of leadership: A survey of theory and research. New York: Free Press. 